\title{
Juvenile summer flounder, Paralichthys dentatus, mortalities in the western Atlantic Ocean caused by the hemoflagellate Trypanoplasma bullocki: evidence from field and experimental studies
}

\author{
E. M. Burreson \& D. E. Zwerner \\ Virginia Institute of Marine Science, School of Marine Science, \\ College of William and Mary; Gloucester Point, Virginia 23062, USA
}

\begin{abstract}
Juvenile summer flounder $(140-200 \mathrm{~mm})$ inoculated with $T$. bullocki by leech vector or syringe in November 1980, and held in flowing seawater tanks all died within 11 weeks. Water temperature during the period of highest mortality ranged from 0.5 to $1.5^{\circ} \mathrm{C}$ and may have been a contributing factor in mortality. No uninoculated control fish died even though held in the same tank. Symptoms of disease were anemia, splenomegaly and obvious ascites. Mortality of feral juvenile summer flunder in the lower York River during January 1981 was also attributable to $T$. bullocki because of identical symptoms to moribund fish in the experiment. Results suggest that the presence of ascites can be used as an estimate of mortality in fishes north of Cape Hatteras.
\end{abstract}

\section{INTRODUCTION}

Attributing mortality to infectious disease in wild marine fish populations is difficult because fishes weakened by disease are subject to predation, or they may die and decompose unobserved. Even more difficult is the accurate determination of the impact of disease on host population size. An excellent discussion of epidemiology of infectious disease in marine fishes and a review of documented epidemics in wild marine fishes has recently been presented by Munro et al. (1983). One of the major impediments to assessing the impact of any disease agent on the population dynamics of its host(s) is the difficulty of estimating mortality rate from prevalence, which is often the only information available. Accurate mortality estimates require a thorough understanding of the ecology of the disease agent/host interaction, and also require experimental studies utilizing the appropriate range of inoculation doses, host life-history stages, and environmental variables. Unfortunately, such experimental studies are labor intensive and costly and, in most cases, so little data are available on disease agent life cycles or other ecological aspects of the association that experiments, if they can be conducted at all, are difficult to interpret. Fortunately, our previous studies have provided us with the biological information to definitely implicate the hemoflagellate Trypanoplasma bullocki (Strout) in mortalities of juvenile summer flounder, Paralichthys dentatus (Linnaeus). 
Species of Trypanoplasma have frequently been implicated as causative agents of mortality in freshwater fishes. However, in many of these early reports, reviewed by Lom (1979), mortality could not reliably be attributed to Trypanoplasma for it was difficult to determine from the field observations whether Trypanoplasma was the causative agent or whether high parasitemias had resulted because of the debilitating effect on the host of some other aetiological agent. More recent research, however, under controlled conditions, has conclusively demonstrated the pathological effects of these flagellates on at least some of their freshwater fish hosts (Putz, 1972; Dyková \& Lom, 1979; Lom, 1979; Lowe-Jinde, 1979, 1980; Woo, 1979).

Trypanoplasma bullocki (Strout) is a parasite of marine and estuarine fishes along the Atlantic coast of the United States and Canada (Strout, 1965; Laird \& Bullock, 1969; Daily, 1978; Burreson \& Zwerner, 1982) and in the northern Gulf of Mexico (Becker \& Overstreet, 1979). The estuarine leech Calliobdella vivida (Verrill) is the vector for this hemoflagellate (Burreson, 1981). The biology of the interactions among the flagellate and its host are discussed by Burreson \& Zwerner (1982) and some aspects of the role of the immune system in controlling the flagellate in summer flounder are presented by Sypek \& Burreson (1982). Trypanoplasma bullocki was first implicated as the causative agent in mortality of a marine fish, the summer flounder, by Newman (1978), although mortality could not definitely be attributed to the parasite at that time.

This communication describes results of an experiment designed to assess the pathology of $T$, bullocki infections in juvenile summer flounder held at ambient conditions and to compare infections in leech-inoculated and syringe-inoculated hosts. Timing of the experiment to coincide with the known time of Trypanoplasma acquisition by feral juvenile summer flounder enabled us to determine that mortality of summer flounder in the lower Chesapeake Bay during January 1981 was attributable to $T$. bullocki.

\section{MATERIAL AND METHODS}

\section{Experimental studies}

Juvenile summer flounder (140-200 mm) were collected by trawl during August 1980 in the lower York River (Chesapeake Bay) and returned alive to the laboratory (see Burreson \& Zwerner, 1982 for map of study area). Fish were held in a shallow, rectangular $(2.5 \times 1.2 \times 0.25 \mathrm{~m})$, covered outdoor tank with flowing unfiltered York River water (salinity about $22 \%$ ) and were fed daily on live grass shrimp (Palaemonetes pugio), live sand shrimp (Crangon septemspinosa), and frozen sliced squid. Even though previous research (Burreson \& Zwerner, 1982) indicated these juvenile fish should never have been exposed to $T$. bullocki-infected leeches, all fish were examined for the presence of hemoflagellates on 30 and 31 October 1980. A small amount of blood was withdrawn from the caudal vessels with needle and syringe, mixed with a drop of $0.6 \%$ saline on a glass slide, covered with a coverglass and examined under low power $(100 \times)$ for live flagellates. Microhematocrit preparations were also examined for flagellates. No flagellates were observed in any fish. On 4 November 1980, flounder were divided into two groups of 85 and 60 fish and held in the same tank but separated by a plastic screen. Preinoculation blood parameter values (described later) were determined for 8 fish from 
the group of 85 to be inoculated (group A) and for 10 fish from the control group of 60 fish (group B). These fish were discarded. On 5 November 1980, 52 flounder from group A were each injected intraperitoneally with about 100,000 T. bullocki in $0.1 \mathrm{ml}$ of $0.6 \%$ saline diluted flounder blood. The remaining 25 fish in group A were placed individually in glass bowls and one $T$. bullocki-infected leech (C. vivida) was placed on each fish. These leeches were laboratory raised, newly hatched individuals that had fed once, two weeks earlier, on a summer flounder heavily infected with $T$. bullocki, and all had large numbers of flagellates in their proboscis sheaths as determined by microscopic examination. All leeches attached and fed, and upon removal $3 \mathrm{~h}$ later, flagellate density in each proboscis sheath was greatly decreased. The 50 fish in group B were each injected intraperitoneally with $0.1 \mathrm{ml}$ of $0.6 \%$ saline. The 52 syringe-inoculated fish, the 25 leech-inoculated fish and the 50 uninoculated (control) fish were all held in the same tank described above but were separated by plastic screens. The 5 November inoculation date approximates the time of Trypanoplasma acquisition by juvenile summer flounder in the Chesapeake Bay (Burreson \& Zwerner, 1982).

Initially, blood parameters and flagellate density were determined weekly for 5 syringe-inoculated and control fish and for 3 leech-inoculated fish. After 5 weeks, the number of hosts examined was reduced. Sample size was necessarily small to avoid using all fish for hematological determinations and thus precluding any analysis of mortality. Fish to be examined were chosen at random and relaxed in tricaine methanesulfonate (MS 222, $200 \mathrm{mg} / \mathrm{l}$ ). Blood was withdrawn from the caudal vessels with needle and syringe and discharged into a dry, heparinized spot-plate well. Blood was tested rapidly in the following order: hemoglobin analysis, RBC count, flagellate count, hematocrit, and erythrocyte sedimentation rate. A fresh preparation in saline for determining flagellate presence, and a smear were prepared from the blood remaining in the syringe.

Hemoglobin was determined by the cyanomethemoglobin method. Blood for RBC count was diluted in Dacie's fluid in an RBC pipet (Blaxhall \& Daisley, 1973) and counts were made in a hemacytometer. Blood for flagellate counts was diluted in $0.6 \%$ saline in a WBC pipet and counts were made in a hemacytometer. Heparinized microhematocrit tubes were used for packed cell volume and for erythrocyte sedimentation rate (ESR) determinations. Hematocrit values were read after $7 \mathrm{~min}$ of centrifugation at $12,000 \mathrm{rpm}$ and ESRs were made at room temperature for $1 \mathrm{~h}$ and then read against a millimeter grid. Blood smears were fixed for $5 \mathrm{~min}$ in methanol and stained for $15 \mathrm{~min}$ in Giemsa. Differential white blood cell counts were made from selected blood smears. At least 100 white cells were examined on each smear and usually 200 to 500 cells were examined. Fish were discarded after examination. Successive bleeding of the same fish was not conducted for fear of unrealistically altering blood parameters. Significance of blood parameter difference was tested by Student's t test. Syringe and leech inoculated fish were combined for all statistical tests.

To further assess survival of ascitic fish, juvenile summer flounder (150-200 mm) collected from the lower Chesapeake Bay and offshore during winter, 1982/83 were held in temperature controlled seawater tanks at $5^{\circ} \mathrm{C}$ or $10^{\circ} \mathrm{C}$. All fish were infected with $T$. bullocki when collected but not all fish had obvious ascites. One small fish $(156 \mathrm{~mm})$ with obvious ascites collected at $5.7^{\circ} \mathrm{C}$ was warmed over $24 \mathrm{~h}$ to $13.5^{\circ} \mathrm{C}$ and then held at that temperature. Fish were held for three months. 


\section{Field collections}

In the Chesapeake Bay, fish were collected with a $30 \mathrm{ft}$ otter trawl during fall, 1980 and winter, 1981. Fish from offshore were collected with a high rise 41 yankee trawl with roller gear during the National Marine Fisheries Service spring groundfish survey aboard R/V Delaware II. All juvenile flounder were collected within $5 \mathrm{~km}$ of shore in depths less than $20 \mathrm{~m}$. Collections from Cape Hatteras south to Ocracoke Inlet, North Carolina were made on 21 March 1981. Collections from Cape Hatteras north to the mouth of Chesapeake Bay were made on 27 March 1981. Aboard Delaware II fish were examined immediately after capture. Each individual was measured to the nearest millimeter (total length), and blood was withdrawn and examined for flagellates as described above. Flagellate intensity was estimated subjectively (always by the first author) as light, moderate or heavy. These categories have been shown (unpubl. data) to correspond generally to hemacytometer counts of less than $250 / \mathrm{mm}^{3}, 250-2,000 / \mathrm{mm}^{3}$ and greater than $2,000 / \mathrm{mm}^{3}$, respectively. The degree of ascites was also recorded.

\section{RESULTS}

\section{Experimental studies}

The temperature in the holding tank, the course of the flagellate infection and the cumulative mortality during the experiment are shown in Figure 1. The hematological determinations are shown in Figure 2. Average parasitemia was highest three weeks post-inoculation in fish in the syringe-inoculated group, but peaked a week later in the leech-inoculated group. Intensity of infection varied greatly in both groups at peak average parasitemia. Hematological parameters for infected and control fish (Fig. 2) were not significantly different prior to inoculation $(p<0.05)$, but diverged gradually as flagellate intensity increased. Hemoglobin, hematocrit and $\mathrm{RBC}$ count values in infected fish were significantly lower than corresponding values in control fish from weeks 2 through 11. Differential leucocyte cell counts remained relatively constant in uninfected fish until week 11. In infected fish there was a general shift to the granulocytic series. Erythrocyte sedimentation rate ranged from 1 to $6 \mathrm{~mm}$, but magnitude was not related to severity or duration of infection.

The only consistent gross pathological manifestation was a progressive ascites first noticeable 4 weeks post-inoculation. By week 9 , the abdominal cavity of all infected fish was grossly distended (Fig. 3). A single leech-inoculated fish died during week 5 (Fig. 1), but during weeks 10 and 11 mortality of infected fish rapidly reached $100 \%$. Water temperature during the period of highest mortality ranged between 0.5 and $1.5^{\circ} \mathrm{C}$. No control fish died during the experiment. Abdominal fluid and blood were withdrawn from all moribund fish. Flagellate density in peritoneal fluid ranged between 5 and 10 times higher than flagellate density in the blood. Smears of abdominal fluid revealed phagocytosis of flagellates by macrophages. Splenomegaly was pronounced in all moribund fish examined.

Survival of naturally infected ascitic fish collected during 1982/83 and held in the laboratory depended on severity of ascites and holding temperature. Fish with severe ascites (Fig. 3) when collected (11 individuals) never survived longer than 3 days at either $5^{\circ} \mathrm{C}$ or at $10^{\circ} \mathrm{C}$. Fish with obvious but not severe ascites (23 individuals) survived 


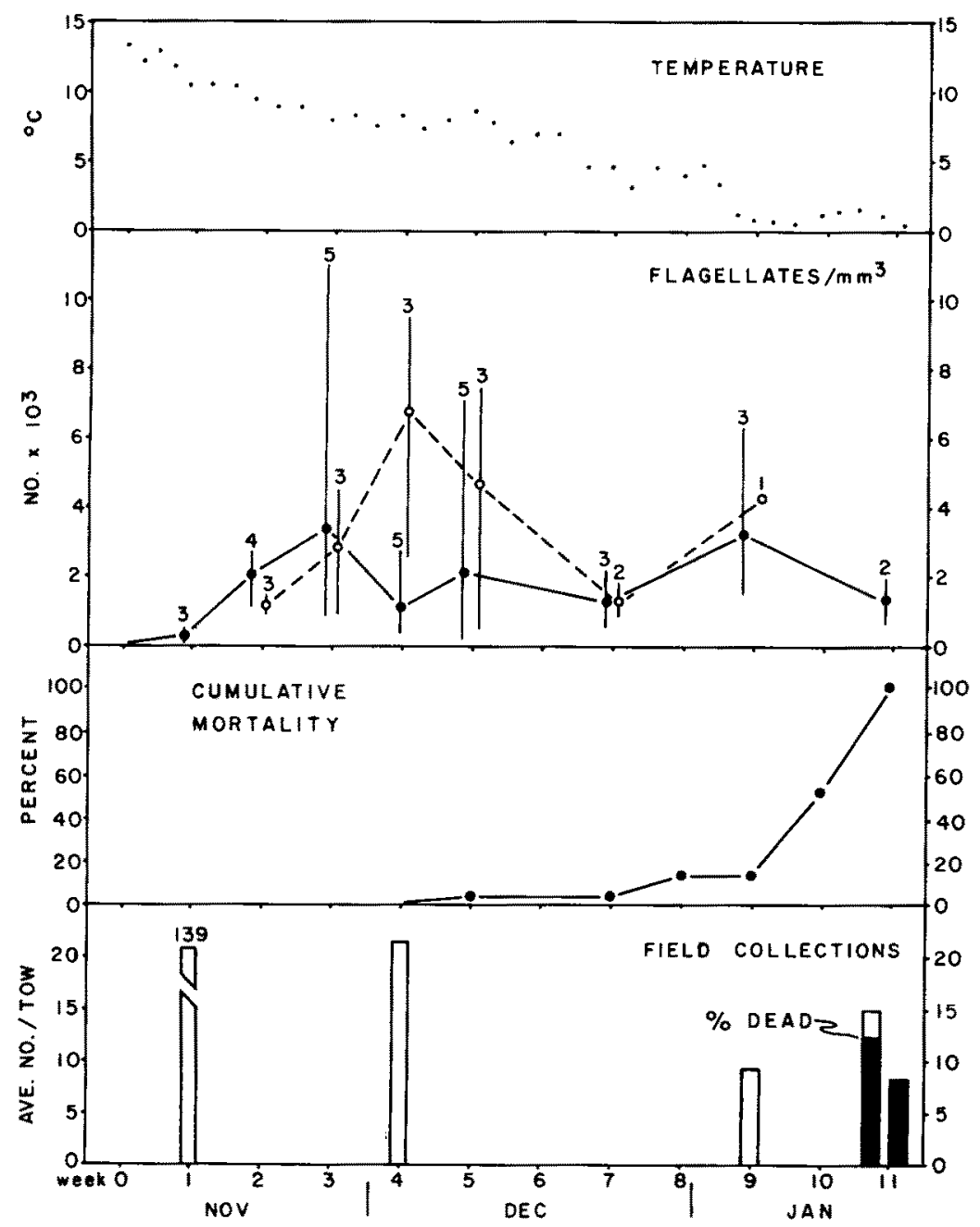

Fig. 1. Results of experimental studies and field collections in the lower York River. Solid line in flagellates $/ \mathrm{mm}^{3}$ connects means for syringe-inoculated fish, broken line connects means for leechinoculated fish. Vertical lines are ranges of intensity, numbers show number of fish sampled

from 2 weeks to 6 weeks at $5{ }^{\circ} \mathrm{C}$, but in all cases ascites progressively worsened and no fish survived longer than 6 weeks. Two fish with obvious ascites held at $10^{\circ} \mathrm{C}$ and one fish held at $13.5^{\circ} \mathrm{C}$ survived for 3 months and were then released. These 3 fish displayed no ascites after 2 weeks at the holding temperature. Infected fish without ascites $(10$ individuals) all survived for 3 months at $5{ }^{\circ} \mathrm{C}$.

\section{Field collections}

Average catch of juvenile summer flounder per trawl in the lower York River is shown in Figure 1. The decrease in catch through the fall probably reflects migration of 


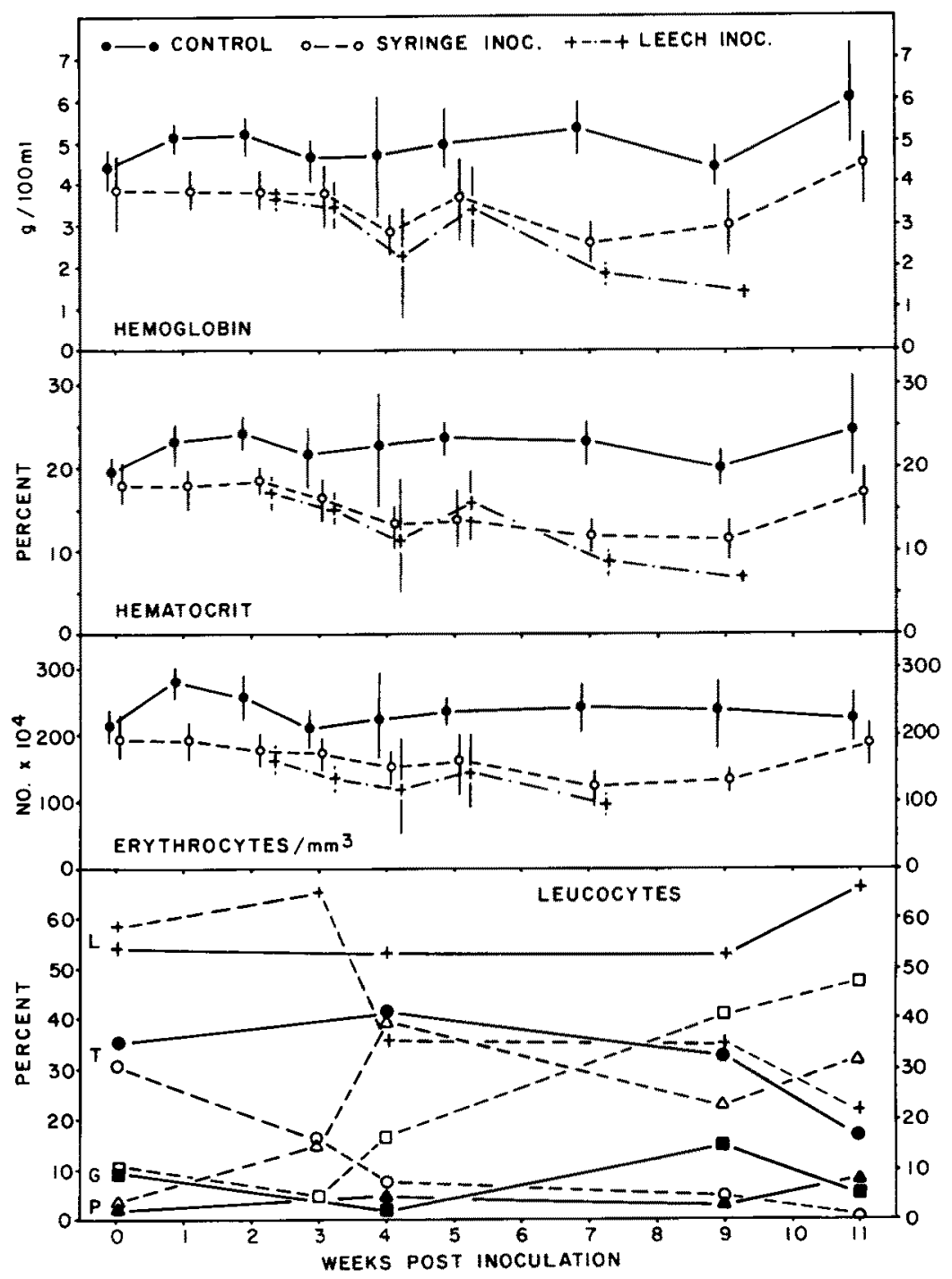

Fig. 2. Hematological parameters for infected and control fish. $L=$ lymphocytes; $T=$ thrombocytes; $\mathrm{G}=$ granulocytes; $\mathrm{P}=$ progranulocytes. Solid lines for leucocytes are control fish, broken lines are infected fish

some fish toward the mouth of Chesapeake Bay and into the nearshore zone outside the Bay. Of 25 individuals examined from the 8 January collection, all were infected with $T$. bullocki and two fish had obvious ascites. Bottom temperature at trawl stations ranged from 2.5 to $3.3^{\circ} \mathrm{C}$. On 19 January, $1981,80 \%$ (47 of 59) of the juvenile summer flounder collected were moribund or dead. All live fish and dead fish from which blood was obtainable were infected with $T$. bullocki, and most fish had noticeable ascites. Bottom temperature in the lower York River was $0.9^{\circ} \mathrm{C}$. On 22 January, 8 summer flounder were 


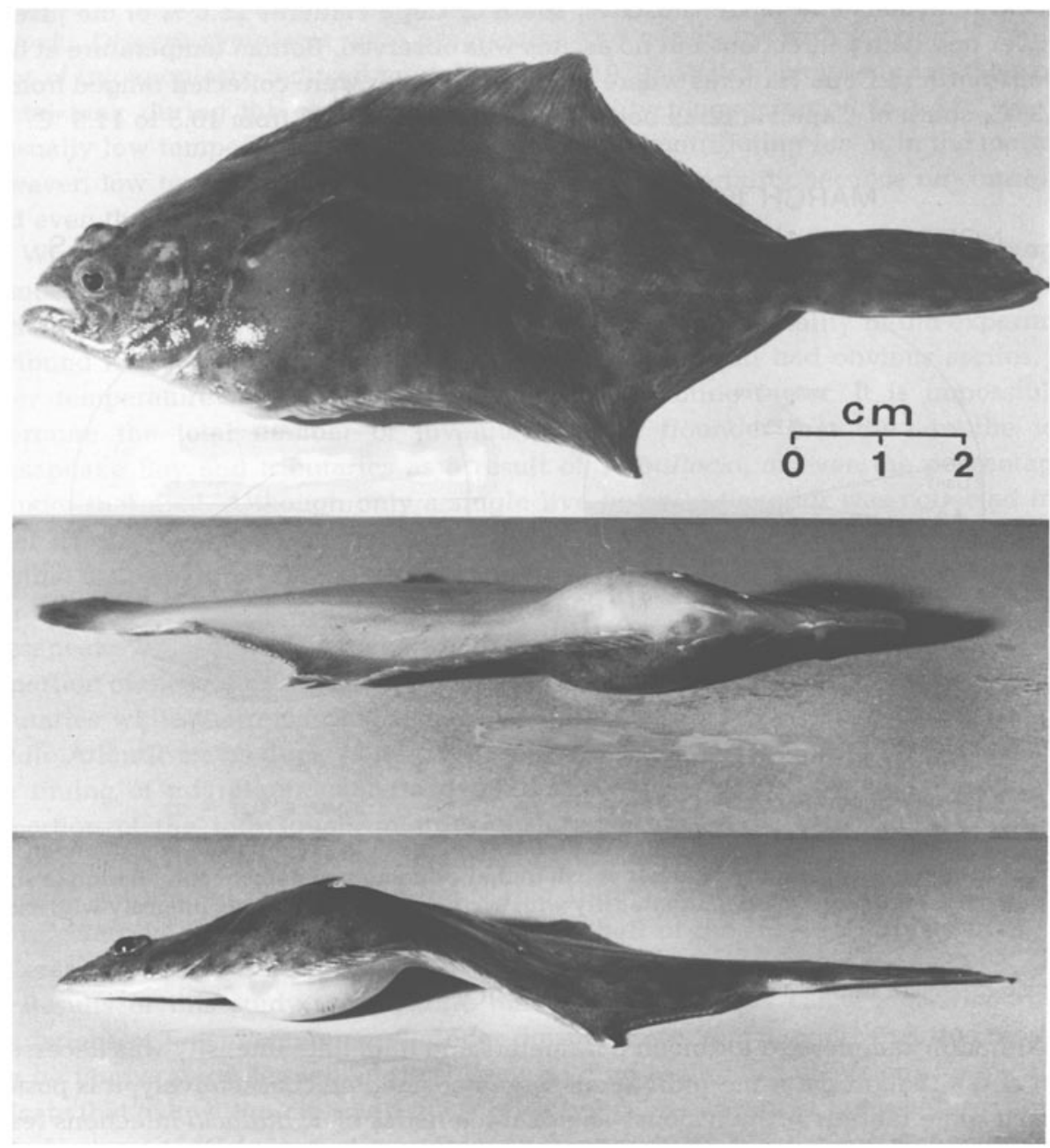

Fig. 3. Severe ascites in juvenile summer flounder from the experiment, 10 weeks postinoculation. Three views of the same individual

collected in a single tow and all were dead. On 10 February 1981, two badly decomposed summer flounder were collected at the mouth of the York River. No summer flounder were collected in four tows on 16 February 1981 in the lower Chesapeake Bay near the mouth of the James River or in six tows in the lower York River on 23 February 1981. On 26 March 1981, no summer flounder were collected in two tows near the mouth of the James River, but one juvenile flounder was collected in one tow at the mouth of the York River.

Intensity of $T$. bullocki infections in summer flounder collected on the March 1981 NMFS groundfish survey from nearshore waters of Virginia and North Carolina are shown in Figure 4 . North of Cape Hatteras $23.4 \%$ of the juvenile flounder had heavy $T$. 
bullocki infections and obvious ascites, south of Cape Hatteras $25.0 \%$ of the juvenile flounder had heavy infections but no ascites was observed. Bottom temperature at trawl stations north of Cape Hatteras where juvenile flounder were collected ranged from 5.3 to $6.3^{\circ} \mathrm{C}$; south of Cape Hatteras bottom temperature ranged from 10.5 to $11.9^{\circ} \mathrm{C}$.

MARCH 1981

\section{NORTH OF CAPE HATTERAS}

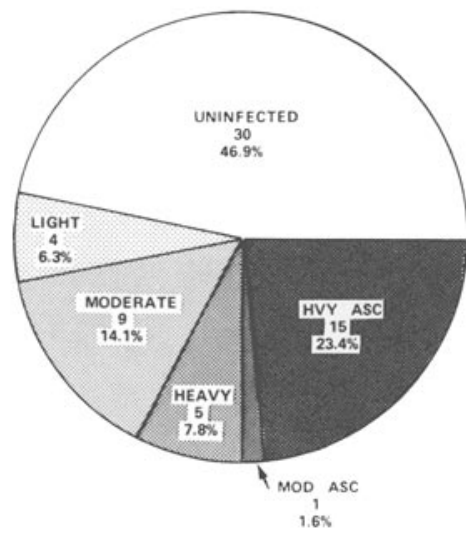

SAMPLE SIZE $=64$
MARCH 1981

\section{SOUTH OF CAPE HATTERAS}

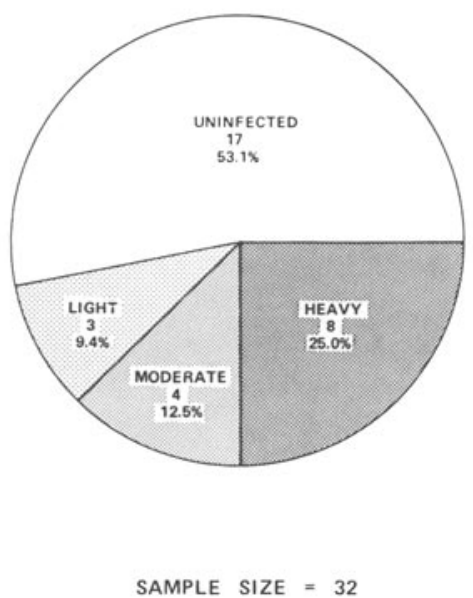

Fig. 4. Computer-generated pie charts of $T$. bullocki intensity in juvenile summer flounder. Each segment lists intensity category, number of fish in that category and percent of total sample size in that category. MOD ASC, moderate intensity with ascites; HVY ASC, heavy intensity with ascites

\section{DISCUSSION}

Although sample size for blood parameters and flagellate intensity was necessarily small and although the same individuals were not sampled consecutively, it is possible to reach some tentative conclusions. The characteristics of $T$. bullocki infections resulting from leech and syringe-inoculation were similar. The leech-inoculated infections peaked one week later than the syringe-inoculated infections and reached a higher average peak parasitemia but considering the variability of intensity at any sampling date the courses of infection for the two inoculation types were similar. Hematological determinations (anemia) and pathological symptoms (ascites, splenomegaly) were also similar for the two inoculation types, and were consistent with those reported for various trypanoplasms in freshwater fishes (Putz, 1972; Lom, 1979; Lowe-Jinde, 1979; Woo, 1979). These results suggest that a syringe inoculation dose of $10^{5}$ is not unrealistic when compared to the effects produced by inoculation by a single, small but heavily infected leech. There have been no attempts to quantify the number of flagellates present in the proboscis sheath of a heavily infected $C$. vivida, but even if it were known, it would be difficult to estimate how many flagellates actually were inoculated into the fish host. The observed shift in infected fish to the granulocytic series compared to uninfected fish was also noted by Hines \& Spira (1973) during Ichthyophthirius infections in carp. 
Results clearly indicate that observed mortality in the experiment was caused by $T$. bullocki. Disease symptoms were progressive and consistent with previously reported cases of trypanoplasm-induced mortality (Lom, 1979). Water temperature in the experimental tank during the period of highest mortality ranged from 0 to $1.5^{\circ} \mathrm{C}$ and this unusually low temperature stress may have been a contributing factor in the mortality. However, low temperature was not the sole cause of mortality because no control fish died even though held in the same tank as the infected fish.

When considered in light of the experimental results, it is clear that dead summer flounder trawled from the lower York River were also killed by $T$. bullocki. Date of mortality in the York River coincided exactly with date of mortality in the experiment, moribund fish were all infected with the flagellate and all had obvious ascites. Low water temperature may have again been a contributing factor. It is impossible to determine the total number of juvenile summer flounder that died in the lower Chesapeake Bay and tributaries as a result of $T$. bullocki, or even the percentage of flounder that died. Although only a single live juvenile flounder was collected in the lower Chesapeake Bay the remainder of the winter, suggesting high mortality, it is possible that the rapid decrease in water temperature in early January from about $5^{\circ} \mathrm{C}$ to near $0{ }^{\circ} \mathrm{C}$ (Fig. 1) may have caused some juvenile summer flounder to migrate out of the Chesapeake Bay into somewhat warmer water along the coast. It is well known that a proportion of the juvenile summer flounder overwinter in the lower Chesapeake Bay and tributaries while the remaining individuals migrate into the nearshore zone along the middle Atlantic states during late fall (Powell \& Schwartz, 1977; Smith \& Daiber, 1977). The timing of migration seems to depend upon temperature, but it is unclear what proportion of the individuals migrate offshore in any given year. Juvenile summer flounder overwintering in the nearshore zone have not been examined routinely for $T$. bullocki, but limited sampling during March 1981 suggests that about $50 \%$ of the fish are infected with $T$. bullocki at that time and half of the infected fish north of Cape Hatteras have obvious ascites.

Results of this study demonstrate that $T$. bullocki does cause mortality in wild populations of juvenile summer flounder during winter and suggest that this mortality may be temperature dependent. Results of holding ascitic fish at various temperatures indicate that fish with ascites will not survive typical winter water temperatures north of Cape Hatteras $\left(5^{\circ} \mathrm{C}\right.$ or less) at least from December through February. Fish with ascites in March may be able to survive until water temperatures warm to $10^{\circ} \mathrm{C}$ in April. Thus, it appears from this study that the presence of ascites in juvenile summer flounder can be used as a measure of mortality north of Cape Hatteras. No ascites was observed south of Cape Hatteras and experimental results, although limited, suggest that ascitic fish could survive $T$. bullocki infections most years because winter water temperatures usually remain above $8^{\circ} \mathrm{C}$.

Future sampling will emphasize overwintering nearshore populations both north and south of Cape Hatteras to obtain more data on T. bullocki prevalence and presence of ascites in these fish. Experimental studies will analyze in more detail the role of temperature in mortality and will attempt to determine why only some infected individuals develop high parasitemias and ascites.

Acknowledgements. We wish to thank J. Sypek and P. Gerdes for assistance with fish collection and the daily task of feeding the experimental fish. Chief Scientist $T$. Azarovitz, National Marine 
Fisheries Service, Woods Hole, Massachusetts, provided space aboard R/V Delaware II, and Watch Chief L. Despres-Patanjo graciously allowed the first author time to sample flounder. This research was supported in part by the office of Sea Grant, NOAA, under Grant No. NA80AA-D-00021 and the Virginia Sea Grant Program through Project No. R/MP-1. Special thanks to M. Newman, NMFS, Oxford, Maryland. Virginia Institute of Marine Science contribution No. 1165.

\section{LITERATURE CITED}

Becker, C. D. \& Overstreet, R. M., 1979. Haematozoa of marine fishes from the northern Gulf of Mexico. - J. Fish. Dis. 2, 469-479.

Blaxhall, P. C. \& Daisley, K. W., 1973. Routine haematological methods for use with fish blood. - J. Fish Biol. 5, 771-781.

Burreson, E. M., 1981. The life cycle of Trypanoplasma bullocki (Zoomastigophorea: Kinetoplastida). - J. Protozool. 29, 72-77.

Burreson, E. M. \& Zwerner, D. E., 1982. The role of host biology, vector biology, and temperature in the distribution of Trypanoplasma bullocki infections in the lower Chesapeake Bay. - J. Parasit. $68,306-313$

Daily, D. D., 1978. Marine fish hematozoa from Maine. - J. Parasit. 64, 361-362.

Dyková, I. \& Lom, J., 1979. Histopathological changes in Trypanosoma danilewskyi Laveran \& Mesnil, 1904 and Trypanoplasma borelli Laveran \& Mesnil, 1902 infections of goldfish, Carassius aurata (L.), - J. Fish Dis. 2, 381-390.

Hines, R. S. \& Spira, D. T., 1973. Ichthyophthiriasis in the mirror carp II. Leukocyte response. - J. Fish Biol. 5, 527-534.

Laird, M. \& Bullock, W. L., 1969. Marine fish hematozoa from New Brunswick and New England.J. Fish. Res. Bd Can. 26, 1075-1102.

Lom, J., 1979. Biology of the trypanosomes and trypanoplasms of fish. In: Biology of the Kinetoplastida. Ed. by W. H. R. Lumsden \& D. A. Evans. Acad. Press, New York, 2, 269-337.

Lowe-Jinde, L., 1979. Some observations of rainbow trout, Salmo gairdneri Richardson, infected with Cryptobia salmositica. - J. Fish Biol. 14, 297-302.

Lowe-Jinde, L., 1980. Observations of rainbow trout, Salmo gairdneri Richardson, infected with Cryptobia salmositica. - J. Fish Biol. 17, 23-30.

Munro, A. L. S., McVicar, A. H. \& Jones, R., 1983. The epidemiology of infectious disease in commercially important wild marine fish. - Rapp. P.-v. Réun. Cons. int. Explor. Mer 182, 21-32.

Newman, M. W., 1978. Pathology associated with Cryptobia infection in a summer flounder (Paralichthys dentatus). - J. Wildl. Dis. 14, 299-304.

Powell, A. B. \& Schwartz, F. J., 1977. Distribution of Paralichthid flounders (Bothidae: Paralichthys) in North Carolina estuaries. - Chesapeake Sci. 18, 334-339.

Putz, R. E., 1972. Biological studies on the hemoflagellates Cryptobia cataractae and Cryptobia salmositica. - Tech. Pap. Fish. Wildl. Serv. U.S. 63, 3-25.

Smith, R. W. \& Daiber, F. C., 1977. Biology of the summer flounder Paralichthys dentatus, in Delaware Bay. - Fish. Bull. U.S. 75, 823-830.

Strout, R. G., 1965. A new hemoflagellate (genus Cryptobia) from marine fishes of northern New England. - J. Parasit. 51, 654-657.

Sypek, J. P. \& Burreson, E. M., 1982. Influence of temperature on the immune response of juvenile summer flounder, Paralichthys dentatus, and its role in the elimination of Trypanoplasma bullocki infections. - Dev. comp. Immunol. 7, 277-280.

Woo, P. T. K., 1979. Trypanoplasma salmositica: experimental infections in rainbow trout, Salmo gairdneri. - Expl Parasit. 47, 36-48. 